\title{
PENERAPAN SIAP DALAM PROSES PENGADAAN BARANG DAN JASA SECARA ELEKTRONIK UNTUK MEWUJUDKAN GOOD GOVERNANCE DI PEMERINTAH KABUPATEN BULELENG
}

\author{
PRATIWI PUTRI, GUSTI MADE INDRA SATRIAWAN, I GUSTI AYU MADE \\ PRADNYANI UTAMI I GUSTI AYU PRADNYA PUTRI, I KADEK INDRA DWI \\ PRIYANTO \\ Jurusan Akuntansi, Universitas Pendidikan Ganesha, Singaraja, Bali, Indonesia
}

\begin{abstract}
Abstrak
Penelitian ini bertujuan untuk mengetahui penerapan SIAP dalam proses pengadaan barang dan jasa Pemerintah Kabupaten Buleleng, kendala yang ditemui dalam penerapan SiAP dan strategi pemerintah Kabupaten Buleleng menghadapi kendala dalam penerapan SIAP. Metode yang digunakan pada penelitian ini adalah jenis metode kualitatif. Pada penelitian ini, penulis menggunakan teknik pengumpulan data dengan observasi, wawancara, dan cara kepustakaan, yakni melakukan pengumpulan data dengan membaca dan merangkum materi dari buku, dan jurnal-jurnal. Hasil dari penelitian ini penerapan aplikasi SiAP dimulai dengan pemberian ID kepada SKPD oleh admin SiAP dari BLP, kemudian SKPD bisa mengajukan paket pengadaan langsung di aplikasi SiAP dengan memenuhi beberapa kebutuhan berkas-berkas, setelah itu berkas tersebut diolah oleh BLP kemudian paket pengadaan yang telah disetujui tersebut akan dilelang di LPSE. Dan jika proses pelelangan di LPSE sudah selesai, maka data pemenang lelang tersebut akan dikembalikan lagi ke aplikasi SiAP dan akan terhubung langsung dengan OPD yang mengajukan paket pengadaan.
\end{abstract}

Kata kunci: Siap, Pengadaan, Good Governance

\begin{abstract}
This study aims to determine the application of SIAP in the procurement process of goods and services of the Government of the Regency of Buleleng, the obstacles encountered in the implementation of SiAP and the strategy of the Government of the Regency of Buleleng facing obstacles in the application of SIAP. The method used in this study is a type of qualitative method. In this study, the authors used data collection techniques by observation, interviews, and the way of literature, which is collecting data by reading and summarizing material from books, and journals. The results of this study the application of the SiAP application begins with giving ID to the SKPD by the SiAP admin from the BLP, then the SKPD can submit the procurement package directly in the SiAP application by fulfilling several file requirements, after that the file is processed by the BLP then the procurement package has been approved it will be auctioned at LPSE. And if the auction process at LPSE has been completed, the auction winner data will be returned to the SiAP application and will be connected directly to the OPD who submitted the procurement package.
\end{abstract}

\section{Keywords: Ready, Procurement, Good Governance}

\section{Pendahuluan}

Seiring dengan kemajuan teknologi informasi dan komputer, kebutuhan akan sebuah sistem yang mampu mempercepat dan meningkatkan efisiensi dan efektifitas pekerjaan dengan biaya yang lebih terjangkau, instansi pemerintah mulai meningkatkan suatu sistem dalam pengelolaan tugas-tugas pemerintahan maupun dalam hal pelayanan. Salah satunya adalah dengan penerapan Sistem Pengadaan Secara Elektronik (SPSE). Sistem Pengadaan Secara Elektronik (SPSE) merupakan aplikasi e-Procurement yang dikembangkan oleh LKPP untuk digunakan oleh LPSE di instansi pemerintah seluruh 
Indonesia. LPSE sendiri adalah unit kerja yang dibentuk di seluruh Kementerian/Lembaga/Satuan Kerja Perangkat Daerah/Institusi Lainnya (K/L/D/I) untuk menyelenggarakan sistem pelayanan pengadaan barang/jasa secara elektronik serta memfasilitasi ULP/Pejabat Pengadaan dalam melaksanakan pengadaan barang/jasa secara elektronik. Selain memfasilitasi ULP/Pejabat Pengadaan dalam melaksanakan pengadaan barang/jasa secara elektronik LPSE juga melayani registrasi penyedia barang dan jasa yang berdomisili di wilayah kerja LPSE yang bersangkutan.

Berdasarkan amanat PerPres No. 54/ 2010 sebagai pedoman dalam penyelenggaraan proses pengadaan barang/jasa pemerintah," BAB XIII PENGADAAN SECARA ELEKTRONIK Bagian Pertama Ketentuan Umum Pengadaan Secara Elektronik Pasal 106 (1) Pengadaan Barang/Jasa Pemerintah dapat dilakukan secara elektronik." Pemerintah Kabupaten Buleleng menerbitkan Peraturan Bupati Buleleng No 78 tahun 2017 mengenai Sistem Informasi Aplikasi Pengadaan (SIAP). Untuk dapat meningkatkan akuntanbilitas proses pengadaan barang/jasa di Pemerintah Kabupaten Buleleng dipandang perlu adanya pemanfaat teknologi informasi dengan penggunaan SiAP ini. Pemerintah Kabupaten Buleleng, Bali melalui Bagian Layanan Pengadaan Sekretariat Daerah setempat pada pertengahan 2017 lalu meluncurkan sistem informasi dan aplikasi pengadaan barang dan jasa yang disebut SIAP (Sistem Informasi dan Aplikasi Pengadaan). Selain meningkatkan akuntanbilitas, aplikasi ini diluncurkan untuk meningkatkan transparansi dan akses persaingan pasar yang sehat, memperbaiki tingkat efisiensi waktu, jarak, serta proses pengadaan barang dan jasa oleh Organisasi Perangkat Daerah (OPD) Pemerintah Kabupaten Buleleng, dengan meminimalisir terbuangnya waktu dan tempat dalam hal pengadaan barang dan jasa, diharapkan Organisasi Perangkat Daerah dapat memfokuskan diri pada pelayanan kepada masyarakat.

Ada beberapa tahapan yang harus dilalui dalam pengadaan barang ini mulai dari pejabat pembuat komitmen atau yang sering disingkat PPK yang mengajukan permohonan pengajuan pengadaan barang ke aplikasi SiAP, PPK kemudian menginput semua dokumen yang diperlukan, selanjutnya dokumen tersebut diterima di front office, dokumen tersebut kemudian di cek oleh kasubag perencanaan, setelah semua berkas sudah terpenuhi dan sesuai dengan ketentuan, kemudian kasubag pelayanan menugaskan para pokja untuk mencari penyedia barang atau jasa yang dibutuhkan di LPSE, hingga pada akhirnya terdapat pemenang lelang dan akan dikembalikan kepada PPK yang mengajukan pengadaan barang/ jasa tersebut.

Dengan bantuan aplikasi SiAP ini pihak SKPD atau PPK yang mengajukan pengajuan pengadaan barang dapat melihat sudah dalam tahap manakah pengajuannya diproses, apakah sudah pada front office atau bahkan sudah pada tahap pelelangan. Dengan aplikasi SiAP ini juga, pemerintah dapat meminimalisir terjadinya kecurangan atau "kongkalikong" antara pihak BLP dengan penyedia barang. Hal inilah yang membuat proses pengajuan barang dan jasa dikatakan semakin lebih transparan dan memiliki persaingan pasar yang sehat. Perubahan proses pengadaan barang menuju lebih baik dengan aplikasi SiAP ini bukan berarti tanpa masalah, masih banyak OPD yang belum memahami betul Sistem ini sehingga belum semua Organisasi Perangkat Daerah menerapkan Sistem Informasi Aplikasi Pengadaan ini, Pejabat pengaju komitmen yang kurang lengkap ataupun salah saat menginput data atau berkas, terdapat ppk yang telah mengajukan pengadaan namun belum masuk dalam aplikasi, dan aplikasi yang belum dilengkapi dengan fitur notifikasi.

Salah satu tantangan yang mempengaruhi keberhasilan penerapan SiAP di Pemerintahan Kabupaten Buleleng ini adalah tersedianya Sumber Daya Manusia yang kompeten dan andal. Faktor lain yang tidak kalah penting adalah komitmen dari organisasi/instansi dalam hal ini yang berwenang dalam pengambilan keputusan adalah pimpinan organisasi itu sendiri yang merupakan penerima dana Dekonsentrasi/Tugas Pembantuan. Faktor selanjutnya adalah infrastruktur yang dapat mendukung kegiatan pengadaan secara online tersebut. Serta Faktor sarana pendukung lainnya berupa teknologi sistem informasi (hardware dan software) yang memadai dalam pelaksanaan SiAP. 
Berdasarkan latar belakang itulah penulis berniat untuk mengetahui lebih lanjut mengenai penerapan SiAP (Sistem Informasi dan Aplikasi Pengadaan) dalam Proses Pengadaan Barang dan Jasa secara Elektronik untuk mewujudkan Good Governance di Pemerintah Kabupaten Buleleng yang merupakan program unggulan Bagian Layanan Pengadaan Setda Kabupaten Buleleng.

Berdasarkan permasalahan diatas rumusan masalah yang dirumuskan yaitu bagaimana penerapan SiAP dalam proses pengadaan barang dan jasa Pemerintah Kabupaten Buleleng, apakah kendala yang ditemui dalam penerapan SiAP dan bagaimana strategi pemerintah Kabupaten Buleleng menghadapi kendala dalam penerapan SiAP.

\section{Telaah Literatur \\ Definisi Pengadaan}

Menurut Weele (2010), Pengadaan adalah perolehan barang atau jasa. Hal ini menguntungkan bahwa barang atau jasa yang tepat dan bahwa mereka yang dibeli dengan biaya terbaik untuk memenuhi kebutuhan pembeli dalam hal kualitas dan kuantitas, waktu dan lokasi. Sedangkan menurut Christopher \& Schooner (2007), Pengadaan atau procurement adalah kegiatan untuk mendapatkan barang atau jasa secara transparan, efektif dan efisien sesuai dengan kebutuhan dan keinginan penggunanya.

Dari pengertian di atas, maka dapat disimpulkan bahwa pengadaan barang dan jasa atau procurement adalah suatu kegiatan untuk mendapatkan barang dan jasa yang diperlukan oleh perusahaan dilihat dari kebutuhan dan penggunaannnya, serta dilihat dari kualitas, kuantitas, waktu pengiriman dan harga yang terjangkau.

\section{Metode-Metode Pengadaan}

Istilah pengadaan secara khusus mengacu pada kegiatan penyediaan barang/jasa pada institusi atau instansi pemerintahan, yang pelaksanaannya dilakukan dengan berpedoman pada peraturan perundangan yang berlaku. Proses pengadaan ini sama halnya dengan proses pembelian atau akuisisi pada sebuah perusahaan. Sistem adalah suatu jaringan prosedur yang dibuat menurut pola yang terpadu untuk melaksanakan kegiatan pokok perusahaan (Mulyadi, 2008:5). Adapun prosedur yang membentuk sistem akuntansi pembelian pada sebuah perusahaan di antaranya adalah prosedur permintaan penawaran dan pemilihan pemasok. Terkait dengan kegiatan perusahaan dalam menentukan jenjang wewenang pemilihan pemasok, terdapat tiga bagian sistem akuntansi pembelian, di antaranya (Mulyadi, 2008:302):

1) Sistem akuntansi pembelian dengan pembelian langsung. Dalam sistem pembelian ini, pemasok dipilih langsung oleh fungsi pembelian, tanpa melalui penawaran harga. Biasanya pembelian dengan pengadaan langsung ini meliputi jumlah rupiah yang kecil dalam sekali pembelian.

2) Sistem akuntansi pembelian dengan penunjukan langsung. Dalam sistem akuntansi pembelian ini, pemilihan pemasok dilakukan oleh fungsi pembelian dengan terlebih dahulu dilakukan pengiriman permintaan penawaran harga kepada paling sedikit tiga pemasok dan didasarkan pada pertimbangan haraga penawaran dari para pemasok tersebut.

3) Sistem akuntansi pembelian dengan lelang. Dalam sistem akuntansi pembelian ini, pemilihan pemasok dilakukan oleh panitia lelang yang dibentuk, melalui lelang yang diikuti oleh pemasok yang jumlahnya terbatas. Prosedur pemilihan pemasok dengan lelang ini dilakukan melalui beberapa tahap berikut ini :

1. Pembuatan rerangka acuan (term of reference), yang berisi uraian rinci jenis, spesifikasi, dan jumlah barang yang akan dibeli melalui lelang.

2. Pengiriman rerangka acuan kepada para pemasok untuk kepentingan pengajuan penawaran harga.

3. Penjelasan kepada para pemasok mengenai rerangka acuan tersebut.

4. Penerimaan penawaran harga dengan dilampiri dengan berbagai persyaratan lelang oleh para pemasok dalam amplop tertutup.

5. Pembukaan amplop penawaran harga oleh panitia lelang di depan para pemasok. 
6. Penetapan pemasok yang dipilih (pemenang lelang) oleh panitia lelang.

Sejalan dengan penentuan jenjang wewenang pemilihan pemasok pada Sistem Akuntansi Pembelian di atas, dalam proses pengadaan barang/jasa pemerintah pun dikenal beberapa metode pengadaan, di antaranya menurut Peraturan Presiden Nomor 54 Tahun 2010 tentang Pengadaan Barang/Jasa Pemerintah adalah sebagai berikut :

1) Pelelangan umum adalah metode pemilihan penyedia barang/pekerjaan konstruksi/jasa lainnya untuk semua pekerjaan yang dapat diikuti oleh semua penyedia barang/pekerjaan konstruksi/jasa lainnya yang memenuhi syarat.

2) Pelelangan terbatas adalah metode pemilihan penyedia pekerjaan konstruksi untuk pekerjaan konstruksi dengan jumlah penyedia yang mampu melaksanakan diyakini terbatas dan untuk pekerjaan yang kompleks.

3) Pelelangan sederhana adalah metode pemilihan penyedia barang/jasa lainnya untuk pekerjaan yang bernilai paling tinggi Rp. 200.000.000,00 (dua ratus juta rupiah).

4) Pemilihan langsung adalah metode pemilihan penyedia pekerjaan konstruksi untuk pekerjaan yang bernilai paling tinggi Rp. 200.000.000,00 (dua ratus juta rupiah).

5) Seleksi umum adalah metode pemilihan penyedia jasa konsultansi untuk pekerjaan yang dapat diikuti oleh semua penyedia jasa konsultansi yang memenuhi syarat.

6) Seleksi sederhana adalah metode pemilihan penyedia jasa konsultansi untuk jasa konsultansi yang bernilai paling tinggi Rp. 200.000.000,00 (dua ratus juta rupiah).

7) Sayembara adalah metode pemilihan penyedia jasa yang memperlombakan gagasan orisinal, kreatifitas dan inovasi tertentu dengan harga/biayanya tidak dapat ditetapkan berdasarkan harga satuan.

8) Kontes adalah metode pemilihan penyedia barang yang memperlombakan barang/benda tertentu yang tidak mempunyai harga pasar dan yang harga/biayanya tidak dapat ditetapkan berdasarkan harga satuan.

9) Penunjukan langsung adalah metode pemilihan penyedia barang/jasa dengan cara menunjuk langsung 1 (satu) penyedia barang/jasa.

10) Pengadaan langsung adalah pengadaan barang/jasa langsung kepada penyedia barang/jasa, tanpa melalui pelelangan/seleksi/penunjukan langsung.

\section{Definisi E-Procurement (Pengadaan Secara Elektronik)}

Internet telah muncul sebagai media efektif dari segi biaya dan dapat diandalkan untuk melakukan transaksi bisnis online. Semakin banyak perusahaan yang mengadopsi media ini dalam melakukan pengadaan barang. Berikut ini terdapat beberapa definisi eprocurement dari berbagai sumber yaitu:

a. Electronic Procurement (e-procurement) di definisikan sebagai penggunaan teknologi informasi untuk mempermudah business-to-business (B2B) bertransaksi pembelian untuk bahan/barang dan jasa (Wu et al, 2007.). Penerapan teknologi sistem informasi untuk memfasilitasi proses pengadaan (procurement) secara terpadu merupakan fenomena yang terus mendapat perhatian dari para manajer, bahkan secara khusus menjadi bahan kajian akademik.

b. Menurut Kantor Manajemen Informasi Pemerintah Australia (Australian Government Information Management, AGIMO): e-procurement merupakan pembelian antarbisnis (business-to-business, B2B) dan penjualan barang dan jasa melalui internet.

c. Menurut daftar kata $X$-Solution: e-procurement merupakan sebuah istilah dari pengadaan (procurement) atau pembelian secara elektronik.

E-procurement merupakan bagian dari e-bisnis dan digunakan untuk mendesain proses pengadaan berbasis internet yang dioptimalkan dalam sebuah perusahaan. $E$ procurement tidak hanya terkait dengan proses pembelian itu saja tetapi juga meliputi negosiasi-negosiasi elektronik dan pengambilan keputusan atas kontrak-kontrak dengan pemasok. Karena proses pembelian disederhanakan dengan penanganan elektronik untuk tugas-tugas yang berhubungan dengan operasi, tugas-tugas yang berhubungan dengan stategi dapat diberi peran yang lebih penting dalam proses tersebut. 


\section{Tujuan e-Procurement}

e-Procurement adalah suatu proses pengadaan barang dan jasa secara online melalui internet, proses ini akan menjadi transparan dan dapat mudah diawasi oleh masyarakat sehingga proses pengadaan barang dan jasa Pemerintah akan adil (fair). Pemilihan penyedia barang dan jasa dengan menggunakan sistem e-Procurement diaplikasikan untuk mewujudkan tujuan pelaksanaan pengadaan barang dan jasa pemerintah, berikut terdapat beberapa tujuan dari implentasi e-procurement:

a. Meningkatkan efektivitas dan efesiensi dalam pengadaan barang/jasa

b. Meningkatkan transparansi dan akutanbilitas

c. Memudahkan sourching dalam memperoleh data dan informasi tentang pengadaan jasa konstruksi

d. Menjamin persamaan kesempatan, akses dan hak yang sama bagi para pihak pelaku pengadaan jasa dan konstruksi

e. Menciptakan situasi yang kondusif agar terjadi persaingan yang sehat antar penyedia jasa konstruksi

f. Menciptakan situasi yang kondusif bagi aparatur pemerintah dan menjamn terselenggaranya komunikasi secara online untuk mengurangi intensitas pertemuan langsung antara penyedia jasa konstruksi dengan panitia pengadaan dalam mendukung pemerintah yang bersih dan bebas dari KKN.

\section{Manfaat e-Procurement}

Menurut Seth Miller dalam artikelnya keuntungan utama e-procurement meliputi menghemat uang, waktu, dan beban kerja tambahan yang normalnya berhubungan dengan pekerjaan tulis menulis. Keuntungan e-procurment tidak hanya meliputi penghematan uang tetapi penyederhanaan keseluruhan proses. Rencana-rencana yang optimal dapat dikomunikasikan dengan cepat kepada penyedia-penyedia jasa, oleh karena itu dapat mengurangi biaya dan pemborosan. Sistem e-procurement membantu perusahaanperusahaan mengkonsolidasikan data tentang pengadaan bermacam-macam barang baik secara langsung maupun tidak langsung. Berikut manfaat dari e-procurement:

a. Pelaksanaan pengadaan barang atau jasa dapat berjalan secara transparan adil dan persaingan sehat

b. Masyarakat luas dapat berperan aktif dalam pelaksanaan pelelangan dan mempermudah masyarakat dalam memperoleh informasi

c. Tidak terjadi pengadaan barang/jasa yang bernuansa $\mathrm{KKN}$, karena semua peserta pengadaan barang/jasa dapat saling mengawasi

d. Tercapainya mutu produk, waktu pelaksanaan, pemanfaatan dana, sumberdaya manusia, teknologi dalam pelaksanaannya

e. Mereduksi tenaga sumber daya manusia, menghemat biaya penyelenggaraan pelelangan dan mengoptimalkan waktu pelaksanaan

\section{Definisi Good Governance}

Good Governance di Indonesia sendiri mulai didengungkan dan terjadi di era reformasi tahun 1998. Pada era tersebut terjadi perombakan sistem pemerintahan besar besaran karena tuntunan proses demokrasi yang bersih. Maka good governance adalah salah satu alat yang tepat dan akhirnya diterapkan saat itu.

Good Governance menurut pengertian World Bank adalah suatu penyelenggaraan manajemen pembangunan yang solid dan bertanggung jawab yang sejalan dengan prinsip demokrasi dan pasar yang efisien, penghindaran salah alokasi dana investasi, dan pencegahan korupsi baik secara politik maupun administratif, menjalankan disiplin anggaran serta penciptaan legal and political framework bagi tumbuhnya aktivitas usaha. Selain itu Bank dunia juga mensinonimkan Good Governance sebagai hubungan sinergis dan konstruktif di antara negara, sector dan masyarakat.

Sedangkan Kashi Nisjar (1997) dalam Domai (2001) mengemukakan bahwa secara umum good governance mengandung unsur utama yang terdiri dari akuntablitas, transparansi, keterbukaan dan aturan hukum. Dan Bintoro Tjokroamidjojo memandang good governance sebagai suatu bentuk manajemen pembangunan, yang juga disebut administrasi pembangunan, yang menempatkan peran pemerintah sentral yang menjadi 
agent of change dari suatu masyarakat berkembang/developing di dalam negara berkembang.

\section{Asas Good Governance}

Berikut ini beberapa asas asas good governance (tata kelola pemerintahan yang baik) yang perlu diketahui :

1) Asas Kepastian Hukum

Asas dalam Negara hukum yang mengutamakan landasan peraturan perundangundangan, kepatutan dan keadilan dalam setiap kebijakan penyelenggaraan Negara

2) Asas Tertib Penyelenggaraan Negara

Asas yang menjadi landasan keteraturan, keserasian, dan keseimbangan dalam pengendalian penyelenggaraan Negara.

3) Asas Kepentingan Umum

Asas yang mendahulukan kesejahteraan umum dengan cara yang aspiratif, akomodatif, dan selektif.

4) Asas Keterbukaan

Asas yang membuka diri terhadap hak masyarakat untuk memperoleh informasi yang benar, jujur, dan tidak diskriminatif tentang penyelenggaraan Negara dengan tetap memperhatikan perlindungan atas hak asasi pribadi, golongan dan rahasia Negara.

5) Asas Proporsionalitas

Asas yang mengutamakan keseimbangan antara hak dan kewajiban penyelenggaraan Negara.

6) Asas Profesionalitas

Asas yang mengutamakan keahlian yang berlandaskan kode etik dan ketentuan peraturan perundnag-undangan yang berlaku.

7) Asas Akuntabilitas

Asas yang menentukan bahwa setiap kegiatan dan hasil akhir kegiatan penyelenggaraan Negara harus dipertanggungjawabkan kepada masyarakat atau rakyat sebagai pemegang kedaulatan tertinggi Negara sesuai dengan ketentuan

\section{Syarat Good Governance} peraturan perundang-undangan yang berlaku.

Menurut Laode Ida (2002), untuk mencapai atau mengimplementasikan Good Governance diperlukan setidaknya lima persyaratan, kelima persyaratan tersebut adalah sebagai berikut:

1. Mewujudkan efisiensi dalam manajemen pada sektor public, antara lain dengan memperkenalkan teknik-teknik manajemen perusahaan di lingkungan administrasi pemerintah negara, dan melakukan desentralisasi administrasi pemerintah.

2. Terwujudnya akuntanbilitas public, sesuatu yang dilakukan oleh pemerintah harus dapat dipertanggungjawabkan kepada pemerintah.

3. Tersedianya perangkat hukum yang memadai berupa peraturan perundangundangan yang mendukung terselenggaranya sistem pemerintah yang baik.

4. Adanya sistem informasi yang menjamin akses masyarakat terhadap berbagai kebijakan dan atau informasi yang bersumber baik dari pemerintah maupun dari elemen swasta serta LSM.

5. Adanya transparansi dalam pembuatan kebijakan dan implementasinya, sehingga hak-hak masyarakat untuk mengetahui keputusan pemerintah terjamin.

\section{Metode Penelitian}

Jenis penelitian yang digunakan pada penelitian ini adalah jenis metode kualitatif. Penelitian kualitatif juga dapat dimaknai sebagai rangkaian kegiatan penelitian yang mengembangkan pola pikir induktif dalam menarik suatu kesimpulan dari suatu fenomena tertentu. Pola berfikir Induktif ini adalah cara berfikir dalam rangka menarik kesimpulan dari sesuatu yang bersifat khusus kepada yang sifatnya umum. Dengan pendekatan ini peneliti 
dapat memperoleh gambaran yang lengkap dari permasalahan yang dirumuskan dengan memfokuskan pada proses dan pencarian makna dibalik fenomena yang muncul dalam penelitian, dengan harapan agar informasi yang dikaji lebih bersifat komprehensif, mendalam, alamiah dan apa adanya. (Anonim, 2017)

Dalam metode kualitatif instrumennya adalah orang, yaitu peneliti itu sendiri. Peneliti adalah instrumen kunci, untuk dapat menjadi instrumen, maka peneliti harus memiliki wawasan dan bakal teori yang luas sehingga mampu bertanya, menganalisis, memotret dan mengkontruksi situasi sosial yang diteliti menjadi lebih jelas dan bermakna. (Suryana, 2010)

Objek penelitian ini adalah aplikasi SiAP (Sistem Informasi dan Aplikasi Pengadaan) yang merupakan aplikasi pengadaan barang dan jasa secara elektronik yang dikelola dan digunakan oleh pemerintah Kabupaten Buleleng dalam proses pengadaan barang dan jasa. Pada penelitian ini, penulis menggunakan teknik pengumpulan data dengan observasi, wawancara, dan cara kepustakaan, yakni melakukan pengumpulan data dengan membaca dan merangkum materi dari buku, dan jurnal-jurnal yang berhubungan dengan penerapan sistem aplikasi sejenis pada suatu organisasi.

Dalam teknik pemeriksaan keabsahan data, peneliti menggunakan teknik triangulasi dalam teori. Menurut Sugiyono (2013;231) teknik pengumpulan data merupakan langkah paling strategis dalam penelitian, karena tujuan utama dari penelitian adalah mendapatkan data. Penelitian ini menggunakan 4 teknik pengumpulan data, yaitu:

\section{Teknik Wawancara}

Menurut Esterberg dalam Sugiyono (2013;231) wawancara merupakan pertemuan dua orang untuk bertukar informasi dan ide melalui Tanya jawab, sehingga dapat dikontruksikan makna dalam suatu topic tertentu. Dalam penelitian ini, peneliti menggunakan teknik wawancara dengan mewawancarai Ir. I Made Budhi Setiawan yang menjabat sebagai Kepala Bagian Pengadaan Pemerintah Kabupaten Buleleng

2. Teknik Pengamatan/Observasi

Sutrisno Hadi dalam Sugiyono $(2013 ; 145)$ mengemukakan bahwa, pengamatan atau observasi merupakan suatu proses yang kompleks, suatu proses yang tersusun dari berbagai proses biologis dan psikhologis. Dalam Penelitian ini, peneliti juga melakukan observasi lansung untuk melihat prosedur penggunan aplikasi SIAP

3. Teknik Dokumentasi

Menurut Sugiyono $(2013 ; 240)$ dokumen merupakan catatan peristiwa yang sudah berlalu. Dokumen bisa berbentuk tulisan, gambar, atau karya-karya monumental dari seseorang. Studi dokumen merupakan pelengkap dari penggunaan metode observasi dan wawancara dalam penelitian ini.

4. Teknik Trigulasi

Dalam teknik pengumpulan data, trigulasi diartikan sebagai teknik pengumpulan data yang bersifat menggabungkan dari berbagai teknik pengumpulan data dan sumber data yang telah ada.

\section{Hasil dan Pembahasan \\ Penerapan SiAP}

Dalam Standar Operasional Prosedur (SOP) Proses Pengadaan Barang/Jasa dari Lembaga Kebijakan Pengadaan Barang/Jasa Pemerintah, berikut tahapan Proses Pengadaan Barang Dan Jasa Pemerintah, diantaranya :

1. PA/KPA masing-masing SKPD menetapkan PPK untuk setiap kegiatan dan mengirimkannya kepada BLP untuk meminta user ID dan Pasword.

2. Admin SIAP akan memberikan User ID dan Pasword kepada PA/KPA/PPK.

3. PPK menyusun rencana pelaksanaan pengadaan Barang/Jasa (RKA/DPA, HPS, KAK, dan Spec teknis) dan menyampaikan kepada PA, setelah itu membuat Surat permohonan yang dilengkapi dokumen pengadaan.

4. Kepala ULP menerima surat permohonan dari SKPD beserta kelengkapan dokumen rencana pengadaan. 
5. Kepala ULP menetapkan anggota ULP yang akan menjadi kelompok kerja (Pokja) untuk paket yang akan dilelangkan dan mengirimkannya kepada LPSE untuk mendapatkan user ID dan Password.

6. Pokja menerima berkas rencana pelaksanaan pengadaanan Barang/Jasa, serta menentukan metode pelelangan dan besaran HPS dan mendapatkan User ID dan Password

7. Jika dokumen tidak lengkap, maka Pokja mengembalikan kepada PPK untuk dilengkapi dan jika lengkap maka di lakukan penyusunan dokumen pengadaan.

8. Pokja Menyusun dokumen pengadaan dan meminta persetujuan PPK.

9. Pokja mengumumkan pelelangan melalui media yang telah di tetapkan (LPSE Provinsi NTB, Website Pemerintah Provinsi NTB).

10. Pokja menyelenggarakan aanwijzing dan menjawab pertanyaan sesuai dengan waktu yang telah ditetapkan Apabila ada perubahan dalam dokumen pengadaan maka pokja menyampaikan berita acara penjelasan kepada PPK sebelum melanjutkan proses lelang ke tahap selanjutnya.

11. Apabila ada perubahan dalam dokumen pengadaan maka Pokja menyusun dan menyampaikan rancangan adendum pengadaan apabila ada kepada PPK.

12. Apabila PPK menyetujui rancangan adendum dokumen pengadaaan maka proses berlanjut dan pokja mengesahkan adendum dokumen pengadaan. Apabila PPK tidak menyetujui adendum maka keberatan tersebut disampaikan oleh ULP pada PA/ KPA.

13. Apabila PA/KPA sependapat dengan PPK maka tidak ada perubahan di dalam dokumen pengadaan dan pokja langsung melakukan proses selanjutnya . Apabila PA/KPA sependapat dengan Pokja, maka Pokja mengesahkan Adendum dokumen pengadaan.

14. Penyedia barang/jasa memasukan dokumen penawaran melalui LPSE sesuai ketentuan yang berlaku.

15. Pokja mengunduh Dokumen Penawaran dari LPSE.

16. Pokja melakukan evaluasi dokumen penawaran.

17.Pokja melakukan expose hasil evaluasi di hadapan ULP dan jika diperlukan dihadapan tim ahli.

18. Pokja menetapkan pemenang lelang dan mengumumkannya melalui SIAP.

19. Masa sanggah terhadap hasil lelang/seleksi selama 5 hari kerja setelah pengumuman hasil lelang/seleksi. Jika tidak ada sanggahan hasil penetepan pemenang maka proses akan berlanjut dan pokja akan menyampaikan laporan proses pengadaan B/J kepada PPK.

20. Jika Ada Sanggahan maka, Pokja menerima sanggahan yang disampaikan penyedia Barang/Jasa.

21. Pokja menjawab sanggahan sesuai dengan waktu yang telah ditetapkan.

22. Jika tidak ada sanggah banding, maka Pokja membuat laporan proses pengadaan dan mengirimkan kepada PPK.

23. Jika penyedia Barang/Jasa tidak puas dengan jawaban sanggah maka penyedia Barang/Jasa dapat melakukan sanggah banding yang disampaikan kepada Gubernur dengan memberikan jaminan sanggah banding. ( Dalam hal menjawab sanggah banding Gubernur dapat membentuk tim untuk menjawab sanggah banding dan Pokja dapat melakukan pendampingaan kepada Gubernur dalam menjawab sanggah banding).

24. Jika sanggah banding diterima oleh Gubernur maka diadakan evaluasi ulang atau lelang ulang dan Jika sanggah banding tidak diterima maka proses berlanjut dan SPPBJ diterbitkan paling lambat 2 hari kerja setelah jawaban sanggah banding.

25. PPK menerima Berita Acara hasil pelelangan sebagai dasar penerbitan SPPBJ Jika PPK tidak bersedia menerbitkan SPPBJ karena tidak sependapat atas penetapan pemenang, maka diberitahukan kepada PA/KPA untuk diputuskan dengan ketentuan ( Apabila PA/KPA sependapat dengan PPK, maka dilakukan evaluasi ulang atau pelelangan dinyatakan gagal, Apabila PA/KPA sependapat dengan ULP, 
maka PA/KPA memutuskan penetapan pemenang oleh ULP bersifat Final dan PA/KPA memerintahkan PPK untuk mengeluarkan SPPBJ, Jika PPK menyetujui Berita Acara Hasil Pelelangan, maka PPK menerbitkan SPPBJ).

26.PPK menunjuk penyedia barang dan jasa yang diusulkan oleh ULP

Penyedia barang dan jasa menyampaikan jaminan pelaksanaan.

27.PPK dan penyedia barang dan jasa melakukan kontrak pelaksanaan pekerjaan.

Mekanisme dan prosedur pengadaan barang dan jasa melalui ULP ini untuk memberikan acuan bagi para pihak yang terkait dengan Pengadaan Barang/Jasa, terutama para PA, PPK dan ULP/PP di lingkungan K/L/D

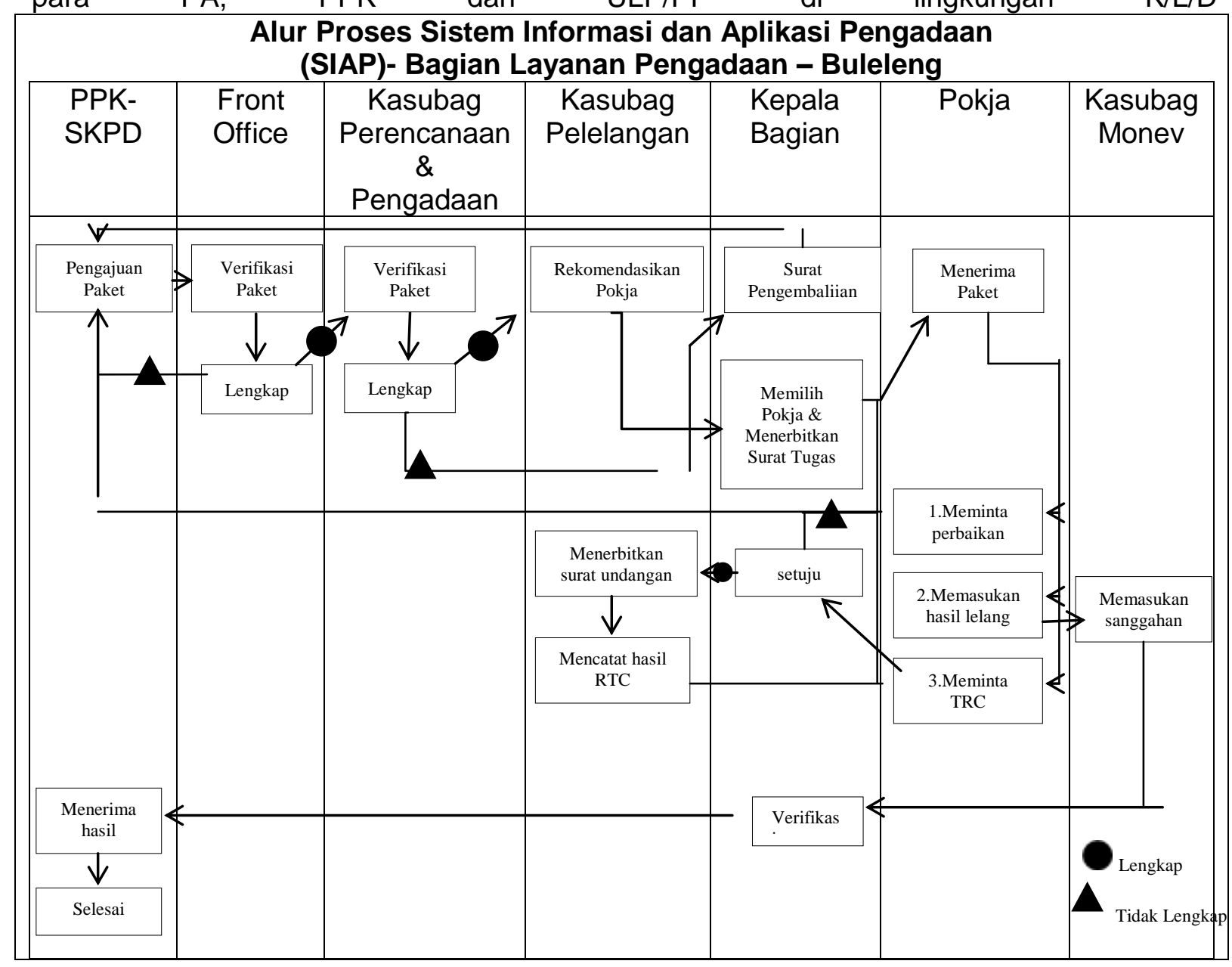

\section{Kendala Penerapan SiAP}

SiAP (Sistem Informasi Aplikasi Pengadaan) Kabupaten Buleleng baru mulai diterapkan sejak 2017 lalu. Aplikasi ini masih menemui beberapa kesulitan dalam penerapannya, diantaranya kesiapan dari pengguna itu sendiri yakni Organisasi Perangkat Daerah Kabupaten Buleleng yang masih dirasa kurang. Dalam penerapannya, OPD masih mengalami beberapa kesulitan dalam pemenuhan kebutuhan berkas-berkas secara online. Karena biasanya OPD melakukan pemenuhan kebutuhan berkas-berkas secara manual dengan kertas, kini OPD dipaksakan untuk bisa memenuhi kebutuhan berkas-berkasnya secara online, mulai dari scan berkas sampai mengirim via online. Kesulitan tersebut diperkirakan diakibatkan oleh kemampuan SDM dari OPD bersangkutan yang masih kurang. Masih banyak pengguna dari SiAP yang belum bisa memahami dan mengerti betul penggunaan sistem tersebut. Masih banyak berkas-berkas terkirim yang salah atau kurang sehingga berkali-kali dikembalikan ke OPD yang bersangkutan. Hal tersebut dianggap memperlambat proses pengadaan oleh Badan Layanan Pengadaan Kabupaten Buleleng, karena otomatis pengadaan dari paket juga akan terhambat jika dalam proses pengajuan (pemenuhan berkas-berkas) masih tersendat. 
Kendala lain yakni kelengkapan aplikasi SiAP yang masih belum lengkap. Seperti belum adanya notifikasi pada aplikasi, error aplikasi sehingga file pdf dari OPD terkadang tidak terbaca oleh sistem atau bahkan pengajuan paketnya belum terbaca.

\section{Strategi Menghadapi Kendala SiAP}

Adapun strategi-strategi yang dilakukan oleh BLP selaku pengelola aplikasi SiAP dalam menghadapi kendala-kendala diatas yakni dengan melakukan sosialisasi-sosialisai dan pelatihan penggunaan aplikasi SiAP secara rutin. Dalam satu tahun masa percobaan penerapan aplikasi SiAP ini, BLP telah rutin melakukan sosialisasi dan pelatihan kepada operator-operator di masing-masing OPD. Dan sejak Januari 2018 lalu, semua OPD telah menyatakan diri untuk siap secara penuh menerapkan sistem pengadaan secara online ini di masing-masing daerahnya.

Kedepannya, pengawasan juga tetap akan dilakukan BLP kepada tiap-tiap OPD agar proses pengadaan secara online ini benar-benar bisa menghasilkan manfaat yang sesuai dengan yang diharapkan.

Strategi lain yang dilakukan oleh OPD adalah dengan menyempurnakan sistem SiAP agar kendala-kendala seperti error yang akan terjadi bisa seminimal mungkin. Kemudian penambahan fitur-fitur pendukung aplikasi SiAP juga telah rencana akan dilakukan kedepannya agar pekerjaan terkait proses pengadaan secara online bisa benar-benar mempermudah pengguna.

\section{Penerapan e-Procurement Dan Good Governance Pemerintahan Daerah}

Berdasarkan observasi dan wawancara yang telah dilakukan, dapat diketahui kondisi perwujudan penerapan e-procurement dalam mendukung Good Governance pemerintahan daerah di Kabupaten Buleleng, yaitu sebagai berikut: Pertama, Meningkatkan Transparansi dan Akuntabilitas. Penerapan e-procurement dalam pengadaan barang dan jasa di Kabupaten Buleleng telah menunjukkan adanya peningkatan transparansi dan akuntabilitas dibanding pengadaan barang dan jasa secara manual. Peningkatan transparansi dan akuntabilitas dapat dilihat dari respond positif dari Organisasi Perangkat Daerah yang mendukung penuh Aplikasi SIAP. Kedua, Meningkatkan Akses Pasar dan Persaingan Usaha yang Sehat. Penerapan e-procurement di Kabupaten Buleleng telah mampu meningkatkan persaingan usaha yang sehat diantara para penyedia barang dan jasa. Hal ini ditandai dengan penerapan salah satu prinsip e-procurement yakni prinsip terbuka dan bersaing. Ketiga, Memperbaiki Tingkat Efisiensi Proses Pengadaan. Berdasarkan hasil wawancara, dapat diketahui bahwa Aplikasi ini sangat membantu mempermudah semua proses pengadaan barang dan jasa dari awal hingga proses pelelangan. Keempat, Mendukung Proses Monitoring dan Audit, tujuan e-procurement untuk mendukung proses monitoring dan audit telah tercapai. Hal ini ditandai bahwa semua data mengenai pengadaan barang dan jasa atau biasa disebut lelang, akan tersimpan terus dalam SIAP, sehingga memudahkan KPK, BPK, Lembaga Kebijakan Pengadaan Barang dan jasa Pemerintah (LKPP), BPKP, dan Inspektorat untuk mengawasi dan memeriksa pengadaan barang dan jasa atau lelang. Kelima, Memenuhi Kebutuhan Akses Informasi secara Real Time. Sesuai hasil penelitian di Kabupaten Buleleng, tujuan e-procurement untuk memenuhi kebutuhan akses informasi yang realtime telah tercapai. Hal ini dapat dilihat dari pengadaan melalui eprocurement, informasi yang diperlukan tentang pengadaan barang dan jasa dapat diperoleh setiap saat. Semua pihak dengan mudah dapat mengakses portal pengadaan melalui media internet.

\section{Simpulan}

Berdasarkan penelitian in, maka dapat disimpulkan bahwa penerapan aplikasi SiAP dimulai dengan pemberian ID kepada SKPD oleh admin SiAP dari BLP, kemudian SKPD bisa mengajukan paket pengadaan langsung di aplikasi SiAP dengan memenuhi beberapa kebutuhan berkas-berkas, setelah itu berkas tersebut diolah oleh BLP kemudian paket pengadaan yang telah disetujui tersebut akan dilelang di LPSE. Dan jika proses pelelangan di LPSE sudah selesai, maka data pemenang lelang tersebut akan dikembalikan lagi ke aplikasi SiAP dan akan terhubung langsung dengan OPD yang mengajukan paket pengadaan. 
Adapun kendala-kendala yang ditemui dalam penerapan aplikasi SiAP ini adalah masih minimnya kemampuan SDM pengguna dari masing-masing OPD dalam menggunakan sistem SiAP, serta masih sering ditemuinya error dan kurangnya fitur-fitur pendukung sistem.

Strategi yang dilakukan BLP untuk mengatasi kendala penerapan tersebut diantaranya adalah melakukan sosialisasi dan pelatihan rutin kepada operator di masingmasing OPD, serta melakukan penyempurnaan sistem yang berkelanjutan kedepannya.

Penerapan e-Procurement Dan Good Governance Pemerintahan Daerah ada lima, yaitu: Meningkatkan Transparansi dan Akuntabilitas, Meningkatkan Akses Pasar dan Persaingan Usaha yang Sehat, Memperbaiki Tingkat Efisiensi Proses Pengadaan, Mendukung Proses Monitoring dan Audit, Memenuhi Kebutuhan Akses Informasi secara Real Time.

\section{Daftar Pustaka}

Anonim. 2017. ," BAB XIII PENGADAAN SECARA ELEKTRONIK Bagian Pertama Ketentuan Umum Pengadaan Secara Elektronik Pasal 106 (1) Pengadaan Barang/Jasa Pemerintah dapat dilakukan secara elektronik." Diakses pada Rabu, 23 Mei 2018, www.bpkp.go.id/uu/filedownload/5/4/1853.bpkp

Anonim. 2018. E-procurement. Diakses pada Rabu, 23 Mei 2018, http://ejournal.uajy.ac.id/333/3/2MTS01736.pdf

Nightisabha, Ita Akyuna., Suhardjanto. Djoko., Cahya, Bayu Tri. 2009. PERSEPSI PENGGUNA LAYANAN PENGADAAN BARANG DAN JASA PADA PEMERINTAH KOTA YOGYAKARTA TERHADAP IMPLEMENTASI SISTEM E PROCUREMENT. JURNAL SIASAT BISNIS (JSB)

Mulyono, Edy. 2016. IMPLEMENTASI PENGADAAN BARANG DAN JASA PEMERINTAH BERDASARKAN PERATURAN PRESIDEN NOMOR 54 TAHUN 2010 (Studi Pada Dinas Pekerjaan Umum Kota Pontianak). Diakses pada Rabu, 23 Mei 2018,http://jurnal.untan.ac.id 